\title{
New Multimodal Designs for Foreign Language Learning
}

By Henrik Kasch

Korrekt citering af denne artikel efter APA-systemet (American Psychological Association System, 6th Edition): Kasch, H. (2018). New Multimodal Designs for Foreign Language Learning. Learning Tech - Tidsskrift for læremidler, didaktik og teknologi, (5), 28-59. DOI: 0.7146/lt.v4i5.111561 


\section{Abstract}

Semiotiske multimodale teorier taler om nye affordanser ("handlemuligheder") i medie- og læringslandskaber, hvilket både teoretisk og empirisk møder genklang i Universal Design for Learning (UDL) -og Computer-Assisted Language Learning (CALL)litteraturen, men pga. de to tilganges henholdsvis neurodidaktiske og teknologiske orientering mangler begge et teoretisk fundament inden for semiotisk multimodalitet og læringsøkologi. Beriget med multimodalitetsteori og økologiske perspektiver kan UDL og CALL krydsbefrugtes til at danne et multimodalt og økologisk bevidst inkluderende design for sprogindlæring. Denne hypotese undersøges teoretisk som en del af et igangværende projekt og dernæst i et empirisk undersøgelsesdesign, der udforsker digital stilladsering. Multimodale og økologiske perspektiver anvendes til at analysere affordanser og økologier i CALL- og UDL-baserede læringsdesign. På baggrund af denne analyse opbygges et principstyret UDL-CALL læringsdesign. Til den empiriske afprøvning foreslås et mixed-methods-undersøgelsesdesign, og foreløbige undersøgelsesresultater præsenteres, der antyder UDL-CALL-designets gangbarhed.

Semiotic multimodality theory speaks of new learning affordances in media ecologies, which is both theoretically and empirically echoed in UDL and in CALL literature, but owing to their neuro-didactic respectively technology-driven standpoints both approaches lack theoretical underpinnings for ecology and semiotic multimodality. Enhanced with multimodality theory and ecological perspectives UDL and CALL can crossbreed, forming a multimodally and ecologically aware inclusive design for language learning. This study from an ongoing project investigates the hypothesis from a theoretical and an empirical perspective, examining digital scaffolds. Multimodal-semiotic and ecological perspectives are used to analyse affordances and ecologies in CALL and UDL learning designs. From this analysis, a principled UDL-CALL learning design is constructed. For empirical testing, a mixed-methods research design is proposed, presenting preliminary results indicative of the design's viability. 


\section{New Multimodal Designs for Foreign Language Learning}

\section{A Multimodal Cross-pollination of Universal Design for Learning and Computer-Assisted Language Learning}

\section{Background}

Universal Design for Learning (Hall, Meyer \& Rose, 2012) has for a long time advocated offering learners a choice between modalities; in Computer-Assisted Language Learning (CALL), digital technologies' usability in language learning has been studied for an even longer time (Beatty, 2010; Mohsen \& Balakumar, 2011; Stockwell, 2007b; Villada, 2009). Despite shared educational interests, so far, the potential of crosspollinating these two approaches has not been investigated. The approaches both concern themselves with IT/ICT and learning, but whereas CALL concerns itself with language learning and ICT with language classrooms in general, UDL addresses inclusive practices in classrooms and sees ICT as tools to instigate such practices. Cross-pollination could thus give rise to an interesting inclusive practice hybrid for ICT-assisted language teaching. This paper argues that the time is ripe for a cross-pollination. The following sections of the paper will discuss the two approaches individually and prepare the grounds for bridging them, examining theoretical underpinnings. For the theoretical analytical discussion, examples will be provided from an ongoing empirical UDL-CALL project exploring input channel augmentation in foreign language learning processes in Danish English as Foreign Language (EFL) classrooms.

\section{CALL}

Many CALL empirical studies have examined language teaching and technology and the gamut of areas in the CALL literature is wide, ranging from (cf. Beatty 2010, pp. 143-144): 
- early behaviouristic language teaching to software

- to advanced simulation games, from

- text editors with language functionalities like spelling checkers and thesauri, to corpus linguistics to

- computer-mediated communication and digital learning designs in general and many other ICT-based technologies.

This means that the scope of CALL is wide and expanding with the advent of innovative and changing ICT technologies. Empirical CALL literature has addressed a host of hypotheses investigating e.g. computer-mediated-communication in language teaching, multimodal glossing, text-to-speech functionalities, and graphical user interface but never coupled with inclusive learning designs (Plonsky \& Ziegler, 2016; Stockwell, 2007; Villada, 2009).

In his rather comprehensive account of CALL teaching and research, Beatty states the need of a CALL model (2010, pp. 142157) and speaks of two pedagogical directions that CALL has been guided by, namely objectivist-behaviouristic and constructivist conceptions of (language) learning. He advocates "constructivist" learning and "problem-orientated" formats, "negotiation for meaning" and "comprehensible output" rather than program interfaces offering "behaviouristic drills" (2010, pp. 85-106, 108-140). Beatty presents a CALL model specifically addressing classroom-teaching CALL (2010, pp. 142-157), drawing especially on Dunkin \& Biddle's (1974) general model of classroom teaching, stemming from a review investigating teacher effectiveness. His CALL model (Beatty, 2010, p. 157) is re-rendered below in Figure 1 (Beatty, 2010, p. 157). 
Figure 1. A Re-rendering of Beatty's

Model of the Study of CALL Teaching

and Learning (2010, p. 157).

Presage variables

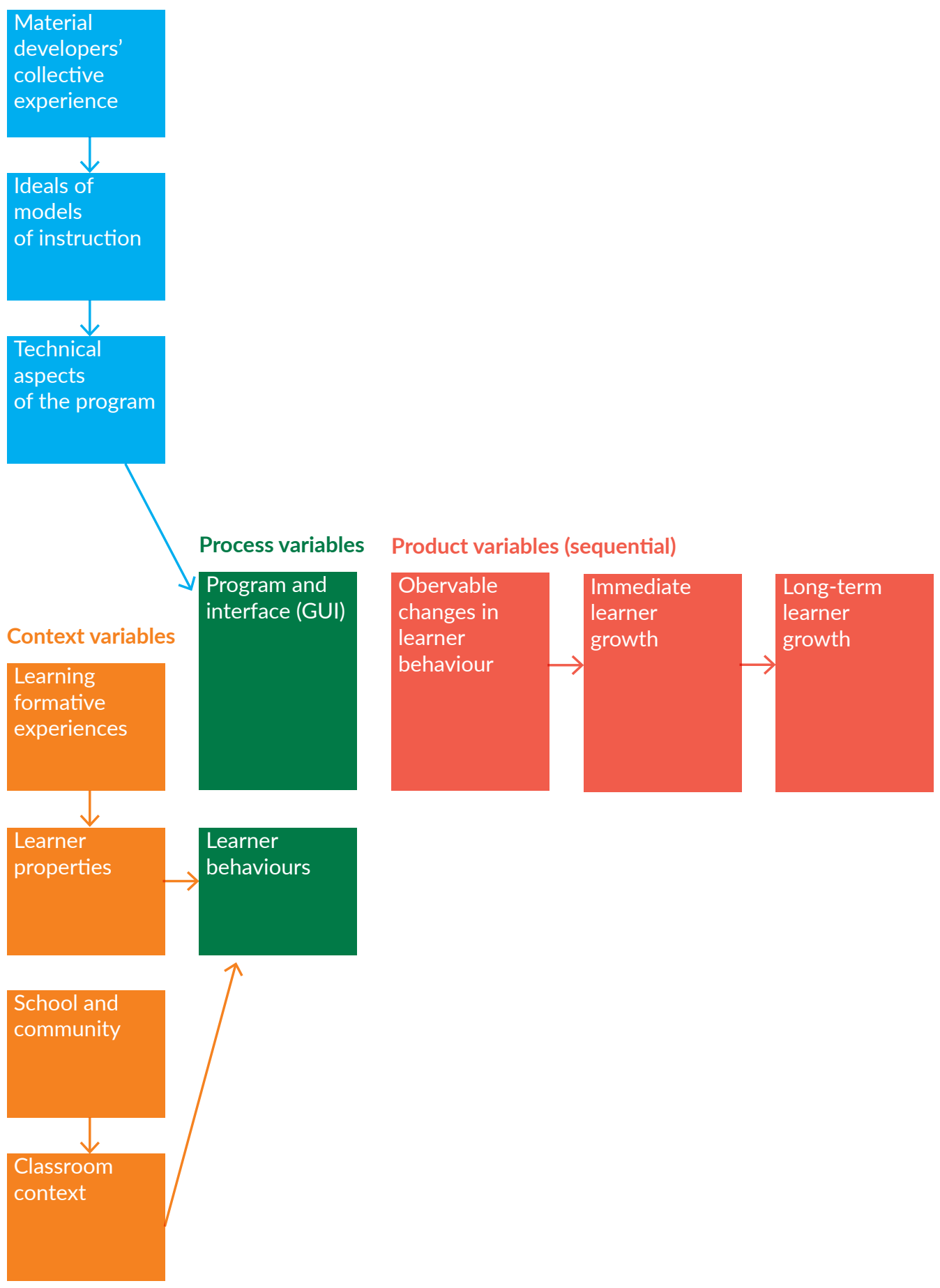

31 Learning Tech 05 | Multimodalitet i didaktikken og klasserummet 
Both Dunkin and Biddle's (1974) and Beatty's (2012) models distinguish four variables: presage variables, process variables, context variables, and product variables. In Beatty's CALL model, presage variables on the left-hand side have internal causal structures, such that top(most) variables determine variables below them. Material developers' collective experience determines their ideals of models of instruction, which in turn shape the technical aspects of the programme, which determines the process variable, "program and the graphical user interface". Similarly, the context variables of the model depict how classroom contexts are shaped by school and community and learner properties by their formative experiences. Learner properties and classroom contexts together influence the process variable "learner behaviour". The process variables then form the basis for the product variables on the right-hand side, depicting a sequential learning process from process-related observable changes in learner behaviour to immediate and - later on - long-term learner growth.

Dunkin and Biddle's original model features presage variables with "teacher formative experiences" having attributes: "social class", "age" and "sex". These are seen to shape "teacher training experiences" and in turn "teaching skills" (Beatty, 2010, p. 146). However, Beatty's CALL teaching and learning model substitutes these presage variables for "material developers' collective experiences" shaping "ideas of models of instruction" and in turn "technical aspects of the program" determining the "program interfaces" (Beatty, 2010, p. 157) substituting for Dunkin and Biddle's "the teacher's behaviour". Beatty's elimination of teachers appears rather contestable vis-a-vis review studies (e.g. Zhang, 2017) highlighting the importance of the teacher's IT (or ICT) skills in ICT-based learning environments. Beatty's apparent omission of relationships between program interface and learner behaviour is also problematic; in fact, in Dunkin and Biddle's original model, the variables "pupil's behaviour" and "teacher's behaviour" were found having a dialectic relationship.

To be fair, Beatty does discuss how CALL and modern ICT produce changes in the "context variables" of Dunkin and Biddle's model. On one hand, Beatty discusses how changes in the components "school and community" produce "classroom contexts" and how "learner formative experiences" lead to "learner properties". Here, Beatty emphasises that generally learners are (Beatty, 2010, pp. 142-157) "socialised" into using ICT 
from their general everyday use. Moreover, school and society's digital age shape this socialisation in tandem with learners' own formative previous and ongoing extramural experiences and interactions with ICT, apparently concurring with Prensky's (somewhat contested) ideas of young people as "digital natives" (Prensky, 2001).

Although Beatty devotes a whole chapter to collaborative CALL and teamwork around computers, inter-learner interaction is absent in his model (Beatty, 2010, pp. 108-140). The model thus embodies a rather conservative transmission-orientated CALL design: software developers do the planning, and the GUI does the teaching with the user/learner left to their own device(s) - irrespective of the developer's possible ideals of models of instruction interactive affording socio-cultural instruction. However, as e.g. modern instructional materials evaluation theory suggests, digital instructional materials also need an evaluation of their relevance vis-a-vis teachers' educational intentions (Bundsgaard \& Hansen, 2011; Hansen \& Skovmand, 2011). Therefore, CALL designs cannot spare the teacher's behaviour, including dynamic planning and implementation and evaluation. In building and informing the CALL and UDL design, I shall, therefore, examine developers, teachers and learners and interaction in UDL-CALL designs more closely.

\section{Universal Design for Learning}

Universal Design for Learning research began in the 80s with the advent of the MacIntosh personal computer when, based on neuroscience and neuro-pedagogy, David Herbert Rose and co-workers at Center for Applied Special Technology (CAST) developed learning materials for students with disabilities including learning disabilities (Hall et al., 2012, pp. 2-17; Rose, 2007). Based on their neuroscientific studies, CAST argue that variability and difference in learners should be considered the norm (Hall et al., 2012, pp. 2-17; Rose, 2007). Evidence stems from brain-scan studies of cerebral topologies in diverse learners' learning processes ranging from neuropsychological laboratory studies of diverse types of learners with learning disabilities to empirical testing of findings in mainstream classrooms. On this basis, CAST propose a neuropsychological learning model and analytical framework for curricular designs dividing the 
brain into three dynamic and interrelated kernel sets of neural networks:

1. "Recognition networks" corresponding to "the what of learning" - dealing with how to "sense and assign meaning patterns" to what "we see" and "how to understand information, ideas and concepts"

2. "Strategic networks" relating primarily to "executive functions" and being "specialized" in "generating" and "overseeing mental and motor patterns" so as "to plan, execute and monitor actions and skills"

3. "Affective networks" specialized in evaluating patterns and assign them emotional significance", enabling the learner to "engage with tasks and learning with the world around us" (Hall et al., 2012, pp. 2-3)

Contrary to popular belief, perhaps, neuropsychological and neuro-didactic approaches like UDL are not just cognitive but rather socio-cognitive and interested in learning environments and inspired by social-constructivist theory (Vygotsky, 1978). In their attempt to translate Universal Design for Learning into operational inclusive practice, CAST have worked out guidelines for each network to flesh out pedagogical recommendations considering the spectrum of learner diversity (see e.g. Hall et al., 2012, pp. 9-21).

Wakefields (2011, p. 3) describes how CAST came to recognise that their original focus on "fixing the learner" was too narrow (cf. also Rose, 2007), and they started examining curriculums and asking themselves the question how curricular limitations disabled learners (Rose, 2007): rather than fix the learner, they would fix the curriculum. UDL guidelines translate CAST's model into three principles together with checkpoints. The Guidelines are informed by three principles each with associated general learning goals (Wakefield, 2011, pp. 14-32). The first principle dealing with recognition networks is to "provide multiple means of representation". Three steps go into this principle encompassing perceptual scaffolding, decoding scaffolding and comprehension scaffolding: 


\section{Provide options for perception}

1.1. Offer ways of customising the display of information

1.2 Offer alternatives for auditory information

1.3 Offer alternatives for visual information

\section{Provide options for language, mathematical expressions and symbols}

2.1 Clarify vocabulary and symbols

2.2 Clarify syntax and structure

2.3 Support decoding of text, mathematical notation and symbols

2.4. Promote understanding across languages

2.5 Illustrate through multiple media

\section{Provide options for comprehension}

3.1 Activate and supply background knowledge

3.2 Highlight patterns, critical features, big ideas and relationships

3.3 Guide information processing, visualisation and manipulation

3.4. Maximise transfer and generalisation

(Wakefield, 2011, pp. 14-15)

This principle illustrates what learning environments can provide to remove potential "input-channel" barriers to learning. Taking CALL down the inclusive practice road, CALL designs can offer an alternative to customary segregated special-education practices by instead letting assistive technologies be shared with the whole classroom - rather than just learners with learning disabilities. The ongoing project at hand is crucially concerned with options for presentation, options for language and options for comprehension and is the first to inquire into EFL and UDLCALL learning designs. Using the UDL research-informed CAST. org platform Bookbuilder (Rose, 2007), I have redesigned existing course book sections to equip learners with an English text-tospeech functionality highlighting each word as it is automatically read aloud. This functionality reaches out to students struggling with reading English, not only learners struggling with general (Danish) literacy problems, but also non-struggling readers who may have difficulties constructing meaning out of the different and notoriously difficult sound-spelling interface in English (see, e.g. "Spelling" in Harmer, 2007). To compound the problem, the 
Danish sound-spelling interface is similarly fraught with nonphonomatic spellings owing to competing principles adopted by the Danish Language Academy (Jervelund, 2007, pp. 11-20).

The present project goes beyond (exploring) this functionality. To wit, the project aims at reaching out to a diversity of learners by providing for each page of the digital material two sound files recapitulating the contents of the page in English and in Danish, respectively. In addition, learners of English struggling with meaning construction in English have access to a content representation in Danish. However, as universal design experience suggests, other learners may use these functionalities for other purposes than the ones immediately intended (Rose, 2007). Among such uses could be close studies of the phonological patterns, recapitulating contents. Ideally, in a multi-ethnic classroom, there should be representations in other mother tongues than Danish, which is, however, beyond the scope of the project.

Further, a compendious multimodal glossary function is provided, providing the learner with the choice to click anywhere in the text they need help. Adhering to inclusive-practice instructional ideals, the design offers compendious glossing, namely lexico-grammatical resources for all words, both content and function words and collocations, including primary verb forms like "is" and "was". The glossary is also experimental in giving the forms of the text rather than insisting on the typical course book lexicographical strategy of base form-based glossing. Doing so, the glossary design reaches out to learners not having mastered morphological analysis and/or dictionary look-ups. Moreover, the multimodal glossing design offers both sound-file and text glossing in both Danish and English.

Compendious glossing may be at odds with vocabulary acquisition studies arguing that a learner can make do with knowing up to 98 percent of the words in a given text (Stæhr, 2015). However, such studies do not focus on special-needs/ struggling learners, and sometimes, as even Stæhr (2015) agrees, not knowing one word in the text may bring about a comprehension failure. Although inclusive practice has been with us for a quite some time, much 'inclusive' teaching practice - at least in foreign language teaching - is still based on remedial and assistive designs trying to compensate/fix the learner rather than universal designs trying to fix the curriculum. Learning platforms - like e.g. the Danish Clio Online - may indeed offer 
text-to-speech functionalities and reduced text versions for differentiated access but do, crucially, therefore, not offer complete content access to struggling learners. Current and traditional learning materials tend to provide a selection of glosses (Kasch, 2015), apparently hoping to guess which glosses are unfamiliar to students.

The glossary design in my e-book draws on Tomasello's $(2003,2009)$ ideas of language acquisition as "usage-based" - see also below. Synthesising Tomasello (2003, 2009) and inclusive practice, we obtain inclusive usage-based language acquisition, recognising the need for repetitive and continued exposition and practice for a diversity of learners, which calls for compendious and not select glossing. Though UDL proposes general principles of how to aid recognition, no nitty-gritty detailed principles obtain for glossing design. Scaffolding language learning and accommodating learner diversity in multimodal learning designs has until now not been a CALL concern, and neither has second language learning in UDL theoretically or empirically.

The ecology and semiosis involved in the communication process of glossing and other scaffolds in an attempt to reach out to a diversity of learners is inherently communicatively complex, attempting to bridge at least two culturally and linguistically diverse semiotic systems - and in a code (explanatory format) decodable to the (very) struggling learners. The project at hand applies a UDL-guided approximation, such that even minimal language-typological differences are considered. This way, syntactically and constructionally (language-typologically) different units are glossed contiguously to reach out to learners with a low contrastive language awareness - in line with research findings in second-language acquisition and (Lund, 2009; Tingbjörn, 1982). Conversely, small sequences of lexical units affording one-for-one translation have been individually glossed. The second overall guideline of UDL dealing with strategic networks and with providing multiple means of action and expression with the goal of having strategic, goal-directed learners: 


\section{Provide options for physical action}

4.1 Vary the methods for response and navigation

4.2 Optimise access to tools and assistive technologies

\section{Provide options for expression and communication}

5.1 Use multiple media for communication

5.2 Use multiple tools for composition

5.3 Build fluencies with graduated levels for support for practice and performance

\section{Provide options for executive functions}

6.1 Guide appropriate goal-setting

6.2 Support planning and strategy development

6.3 Facilitate managing information and resources

6.4 Enhance capacity for monitoring progress

(Wakefield, 2011, pp. 22-23)

This guideline inspires CALL learning designs by addressing learner interaction and providing a choice of responses and enabling the use of their best "output channel", but also in terms of developing executive functions for managing the learning process. Although the present project primarily targets inclusive practice and recognition networks, it does deal with "strategic networks" by providing for each page a response field (in Danish and English) to a question asking the student to reflect on what they have just read. Moreover, the recapitulation sound files in English and Danish of the page content offer a model of what to decode and thus both scaffold strategic networks operations.

The third guideline, dealing with "affective networks", is to "provide multiple means of engagement" and is spelt out as:

\section{Provide options for recruiting interest}

7.1 Optimise individual choice and autonomy

7.2 Optimise relevance, value and authenticity

7.3 Minimise threats and distractions

\section{Provide options for sustaining effort and persistence}

8.1 Heighten salience of goals and objectives

8.2 Vary demands and resources to optimise challenge

8.3 Foster collaboration and community

8.4. Increase mastery-oriented feedback 


\section{Provide options for self-regulation}

9.1 Promote expectations and beliefs that optimise motivation

9.2 Facilitate personal coping skills and strategies

9.3 Develop self-assessment and reflection

(Wakefield, 2010, pp. 22-23)

This UDL guideline concurs with Dörniey's Motivational Strategies in the Language Classroom (2001) as well with motivational thinkers exploring self-regulation or self-efficacy like Bandura (1994), whom Beatty (2010, pp. 85-106, 108-140) also cites when dealing with CALL and learner autonomy. This guideline is of inspiration to CALL designs in providing design strategies for dealing with affect, agency and motivation. In the present study, though, affective networks has only been indirectly addressed and therefore, for practical reasons, leaves this UDL component for other resources in the classroom than the learning material itself to deal with, i.e. teachers and learners. I shall revert to this problem in the section below.

CAST cites a vast body of research literature in empirical and theoretical support of their individual guidelines. However, studies cited just concern the checkpoints themselves - not necessarily in UDL learning environments. In fact, as Ok, Rao, Bryant and McDougall (2016) remark in their review article of UDL empirical research in regular non-remedial education learning environments, longitudinal studies indicate positive impacts on learning intake, but studies do not show which or how UDL components are efficient. In Matthew Capp's recent meta-analysis of UDL effectiveness (Capp, 2017) in empirical studies from 2013 to 2016, similar findings are presented. The present project, being a componential study of recognition networks, can help contribute to deal with this apparent dearth in UDL research.

\section{Scaffolding, Multimodality and Affordance Theory and Ecological Perspectives}

In computer-assisted learning, the (scaffolding) functionalities we are facing are digital and multimodal and found in classroom ecologies. Scaffolding theory derives from the study by (Wood, Bruner \& Ross, 1976) of tutoring 3-5-year-olds. Though, there is no mention, Vygotskyan notions, "internalisation" and "zone of 
proximal development" (Vygotsky, 1978, pp. 52-57, 79-91), seem to permeate their experimental tutoring study. Wood et al.'s (1976) building-block experiments with 3-yr-old, 4-yr-old and 5-yr-old subjects in an experiment paraphrase Vygotsky's experimental psychological methodology (Vygotsky, 1978 (1935), pp. 58-62) advocating the study of learning in vivo, rather than a Piagetstyle measuring of stages resulting from learning processes left unexplained. In Wood et al.'s (1976) study, a tutor provides "scaffolding functions" helping the child learn to perform the "next step" in the task (Wood et al., 1976, p. 98) resonating with Vygotsky's “zone of proximal development" (ZPD) (1978). These "scaffolding' functions of the 'scaffolding' process" comprise six components (cf. Wood et al., 1976, p. 98):

1. recruitment (the tutor to enlist the problem solver's interest in and adherence to what the task requires)

2. reduction in the degrees of freedom (the tutor is to simplify task by lowering the number of acts involved for the child to arrive at a solution. "The 'scaffolding' tutor fills in the rest and lets the learner perfect the component sub-routines that he can manage")

3. direction maintenance (the tutor is to keep learners on track and on task)

4. marking critical features (the tutor is to show "discrepancies" between the learner's product and the ideal or goal product)

5. frustration control (the tutor is to see that "problem-solving is less threatening and leads to less "stress" when the tutor's around than when they are not, the "major risk" being tutee dependence on tutor)

6. demonstration (the tutor is to "demonstrate" or "model solutions to a task" which may involve explaining and performing previous steps accomplished by tutee and together with ideal next steps to be taken for the tutor to "imitate back" steps "in a more appropriate form", i.e. amenable to solving the problem at hand)

Unlike Wood et al.'s (1976) study, the present project examines digital scaffolds and in foreign-language classrooms. Focussing on recognition networks scaffolding, the present project provides a range of tutorial scaffolds, namely a "demonstration" of how to make sense of the page at hand by the recapitulation 
functionalities in Danish and English. Glossary functions further serve to reduce learners' steps as would be associated with consulting multiple senses of dictionary entries as well as sentence meaning construction helped on by contiguous glossing, which also parallels "reducing degrees of freedom" of the scaffolding process. However, to avoid perceived undue "reductions in the degrees of freedom" with proficient learners, instructional meta-scaffolding is used to show students that glossing scaffolds and other scaffolds are meant to help out rather than limit translations/understandings.

The components "direction maintenance" and "recruiting interest" resonate with executive function, (strategic) networks scaffolding and affective networks scaffolding. The study does not, cf. above, directly address the latter, leaving it for e.g. teaching practices themselves to recruit interest. However, the access to help for each word (including function words) should help to reduce anxiety and control frustration, also resonating with strategic networks UDL principles.

In digital learning environments, Pea (2004) argues that of late "scaffolding" has become a "vague" but also "complex" and wide concept, lamenting that no distinction is made between "scaffolding" and "distributed intelligence". When e.g. in digital learning formats, scaffolds persist, i.e. are not "faded" dynamically to match evolving ZPD, Pea (2004) argues that such non-fading scaffolds should be considered "distributed intelligence". Pea also seems to imply (2004) that such pseudoscaffolds may do learners a disservice, keeping them from moving on from a scaffolded level of attainment. Using Pea's distinction, the supports in the CALL literature (Mohsen \& Balakumar, 2011; Villada, 2009), like glossaries and text-tospeech functions should thus be considered "distributed intelligence". However, learners accessing non-faded scaffolds are likely to do so as part of their learning process the way a child may ask the tutor for help to perform the next step (Wood et al., 1976) or as part of a regular "internalisation" process (Vygotsky, 1978). Even doing it for fun might lead to "unintended learning" (see e.g. Schmidt, 2010). Non-fading does therefore not per se imply a "distributed intelligence" functionality - as long as the child or learner uses the functionality to move into their ZPD. Metascaffolding is still needed, though, to optimise or avoid protracting internalisation processes owing to misguided (over-) use. 
However, in a wider (ecological) perspective, non-faded digital scaffolds, as used in the present project, can be seen as affordances, cf. below, and not as disservices to learners. Modalities in a digitally scaffolded multimodal design, however, help in different ways owing to their limitations and potentials, which is of course of significance to inclusive practice-oriented designs: the topic of the next section.

\section{Multimodality}

In his theory of modality and literacy, Kress crucially distinguishes space-based modes from time-based modes (i.e. modalities):

99 The second characteristic is that in representation and in communication we always use a large number of modes of representation. Each such mode has particular potentials and limitations. In earlier chapters I have pointed to some of these. For example, there is the fundamental opposition of the potential space-based modes and time-based modes. In the former the possibilities offered by a flat surface seem to lead in children's early representations to a predominance of analytic and classificatory representations, arranged as displays. In the latter, in language, children of the same age produce stories which have actions shaped into basic narrative structures.

(Kress, 1997, p. 154)

He further argues that children and adults have different proficiencies and adults may go beyond the "particular potentials and limitations" of the mode in question:

99 In the adult forms of spatial and temporal communication modes, it is possible to represent actions and narrative in the former, and display in the latter, yet it seems that there is still a fundamental difference: one is better suited to one range of tasks, and the other to a different range. (Kress, 1997, p. 154) 
Kress argues that multimodal literacy beyond "representations produced by children as a matter of course" and especially multimodal communication skills require tuition. In Kress' studies, "space-based" modes (modalities) are thus associated with "classificatory and analytic meaning", and time-based modes with "narrative" meaning. For digital multimodal scaffolds, then, Kress' studies entail that conveying narrative meaning calls for sound or connected visual sequences (films, cartoon strips), whereas classificatory meaning is more easily conveyed in "synchronous" presentations. Bernsen (2008), discussing GUI design in human-computer interaction, presents the similar argument that sound-based GUIs need complexity reduction and other adaptation. Bernsen (2008) further states - very much like Kress (cf. above) - that multimodal designs not respecting modality features leads to inordinate cognitive loads, but also argues that the less complexity, the more opportunity for direct translatability between modalities.

Like the present project, Kress (1997) and Jewitt (2005) and other multimodal semiotics theorists examine education in the digital multimodal age (cf. Baldry \& Thibault, 2006; Baldry \& Thibault, 2008), but build on (Hallidayian) social semiotics and functional linguistics. Bazalgette \& Buckingham (2013) criticise their approaches for being semiotically too linguistically or visual image-oriented, arguing that comprehension of filmic multimodality is only rudimentarily understood in mainstream multimodality semiotics, cf. also Forceville (2007). Kress' analysis of "limitations" and "potentials" are not contested in the critiques by Forceville (2007) or Bazalgette \& Buckingham (2013). Rather, an important point made (Bazalgette \& Buckingham, 2013) is that children have attained a basic understanding of interpreting filmic resources like narratives, actors, settings and events before entering school, which is not accounted for in linguistically oriented semiotic multimodal analyses of filmic vehicles of communication.

UDL guidelines (cf. above) ask the teacher and designer to use multiple representational formats, apparently without further ado, to embrace learners' diversity in input channel mastery or mode/modality mastery. However, without an awareness of limitations and potentials (Kress, 1997, p. 154), scaffolding designs may fail. How to apply Kress (1997, p. 154) practically, however, in tandem with UDL principles is apparently no trivial matter. In the present project, space- 
based picture scaffolds are canonically used to show artefacts and non-narrative phenomena, representing a "classificatory use”. However, in inclusive practice and outside Kress' broad discussion, the designer will soon realise that many concepts are not easily conveyed using space-based pictorials. When subject to learners' "ongoing refinement" of perceptions/ construals (cf. Gibson's Affordance Theory below), scaffolding the understanding of e.g. abstract concepts appears to involve using illustrative events/situations of which the concept is an example or a property, which in turn necessitates narrative exemplification and hence not immediately compatible with a space-based modality.

Further, intermodal translatability (cf. Bernsen, 2008) allows time-based sound and text scaffolds to be used to represent single- or multiple-word translations or paraphrases if reflecting quotidian concepts alignable with the learner's life world and experience (cf. Beatty's "formative experiences and learner properties"). In addition, drawing on e.g. Bazalgette \& Buckingham (2013), we can use a narrative(-based) exemplification to explain abstract glosses not aligned with learners' experiential worlds. In this way, we can extend Kress' ideas of potentials in modes if translating classificatory meaning into a narrative representation (and vice versa), aiming to have a fair choice of representational formats reaching out to a diversity of learners.

The UDL-CALL design of multimodal inclusive scaffolds can thus learn from the findings in multimodal semiotics (Kress, 1997; Bazalgette \& Buckingham, 2013) as well as multimodality theory in human-computer interaction (Bernsen, 2008). Without knowledge of the potentials and limitations of a mode or modality, i.e. its affordances in inclusive language learning classrooms, intended scaffolds may become counterproductive. To take a closer look at the entire set of affordances of the UDLCALL classroom, the next section will examine affordance theory and ecological perspectives.

\section{Affordance Theory and Ecological Perspectives}

As previously suggested, the original CALL design model provided by Beatty (2010) partly ignores classroom ecologies, apotheosising programs to a teacher status, excluding a host of 
affordances in the classroom. Moreover, no theory of second language acquisition and teaching features in Beatty's design. To inform the UDL-CALL design on these dimensions, we shall look at ecological perspectives and affordances in the UDL-CALL classroom.

Affordance theory goes back to James J. Gibson, studying the ecology of visual perception considering both technical aspects of light rays and perception (Gibson, 1986) and the conceptualisation and categorisation involved in perceptual interaction with environments. Gibson (1986, pp. 127-128) discusses the need for a new noun, "affordance", derived from the verb "afford" (to 'allow' or 'enable'), as a central theoretical construct. He argues that animals and the human species alike act in and interact with surroundings according to what the surroundings afford, i.e. recognising its interactional potential. This establishes a wholly other understanding of human perceptual conceptualisation, jettisoning visual conceptual contruals, such as type-token hierarchical human cognition in perception. Instead, Gibson proposes an epistemological model based on interactional ecological potentials, i.e. "affordances" (1986, pp. 127-144). Unlike the "orthodox psychology" of his day and age (1986, pp. 238-262), he argues that perceptual cognition rather relies on what perceptual clues the environment offers. Thus, in his ecological approach to visual perception, Gibson escapes an epistemological contradiction that "great minds" have tried to solve before him, namely, that of "sensory input units" being thought of as a series of "glimpses" (1986, pp. 240241). Gibson's approach, on the contrary, sees the capacity for having "a flow of visual awareness" as the starting-point, allowing humans and animals to explore their environment using ambulatory and ambient perceptual processes to learn from ecological interaction to refine their perceptual understanding of affordances of "surfaces", "textures" and "objects" (1986, pp. 238262, 127-144).

Ongoing refinement means, as Gibson argues, that misconstrual of affordances may occur until interactionally or scientifically-technologically afforded or carried out (1986, pp. 238-262). Gibson's theory of perception dovetails with the empirically informed usage-based approach to language learning (Tomasello, 2003, 2009). Here, the human capacity for a perceptual flow appears to be a prerequisite and that children learn a language in an ecological niche providing affordances 
with exposure to temporally sequenced contiguous linguistic elements, context, and scaffolded practice with peers and parents.

Gibson's theory of perceptual flow is also an underlying assumption in scaffolding theory: without contiguous perception, the child cannot understand (the affordances of) the scaffolding process - or learning processes in general: without the capacity for a perceptual flow (as opposed to perceptual frame by perceptual frame perception) pedagogical processes are simply not afforded. Viewing classrooms as ecologies does not per se, though, preclude non-ecological (like e.g. structural or non-interactionist) structural (non-interfaced) approaches to language acquisition like Krashen's Monitor hypothesis (Krashen \& Terrel, 1988; Zafar, 2010) or Chomskyian linguistics (Chomsky, 1968), but furnishes us with a coherent understanding of classrooms as ecological niches. Tomasello's research (2003, 2009) into language acquisition does not, moreover, hypostasise a language acquisition device (LAD) and a universal grammar (UG), as is customary in prominent non-ecological approaches to language acquisition (Krashen \& Terrel, 1988; Zafar, 2010; Chomsky, 1968). The LAD and UG assumptions are, unlike usage-based theory, neither unaligned with the state of the art of biological research (Turner, 1998, pp. 140-198); even admitted by (Pinker, 1995, pp. 292-300) nor with empirical research into children's language acquisition (Tomasello, 2003, 2009).

Ecological perception theory is at the heart of socioculturalecological approaches to language learning, such as e.g. van Lier (2000, 2004) and Gibbons (2006), who both use "affordance theory" to apprehend classrooms as ecologies. Studying semiosis and semiotics, both van Lier and Gibbons concern themselves with extending the "semiotic budget" and "prolepsis" of the classroom to "bridge discourses" (Gibbons, 2006). Their research advocates for the teacher to instigate ecological scaffolding classroom practices (Gibbons, 2006) or, as van Lier (2006) argues, to address (learner) "action and identity", i.e. fostering active learner agency and classroom learning processes that socially and interactionally develop agentive learner identities.

Discussing affordances in the language classroom, Gibbons (2006, pp. 235-245) highlights the importance of "proleptic discourse" building on van Lier's notion of "prolepsis" (2004, p. 152): 
Ellipsis occurs in sentences or texts when information is left out because it is considered redundant, and the listener (or reader) is supposed to be able to fill in the missing pieces. However, the speaker (or writer) who uses ellipsis does not explicitly check or facilitate the listener's interpretive processes, or invite the listener into a shared intersubjective space. As I explained above, when Rommetveit (1974) proposed the notion of prolepsis, he was thinking of a speaker who gives the hearer clues for the enlargement of common ground without spelling out every detail. Proleptic discourse therefore is aware of gaps in understanding and invites the less-competent into sharing with the morecompetent. Whereas ellipsis can be dismissive (or at best indifferent), prolepsis is always invitational and generous [...] (van Lier, 2004, p. 152)

van Lier builds on Rommetveit's notion of "prolepsis", which in turn builds on Clark's and Brennan's construct, "common ground" (Clark, 1996; Clark \& Brennan, 1991) looking into how listeners and speakers align around shared understanding and cognition in conversation. "Prolepsis" is Rommetveit's augmentation of Clark's "mechanism" for enlarging "common ground" in discursive conversation. van Lier uses this construct in his ecological tack on language learning and teaching, arguing for teachers to aim for sustainable discourse with a(/an) (constant) awareness of gaps in understanding.

Gibbons' analyses of her ecological genre- and SFL-based approach (Martin \& Rose, 2005) to teaching and learning (Gibbons, 2006, pp. 71-120) discusses examples of "proleptic discourse" leading to "collective scaffolding" in language learning (cf. Donato, 1994) and to levels of shared understanding beyond prior individual levels of understanding, augmenting the "common ground". In an inclusive practice UDL understanding, van Lier's (2004, p. 152) and Gibbons' (2006) ideas of prolepsis are expanded for teaching to reach out to all the individual learners' current understandings and provide them with multiple means of proleptic representation (Hall et al., 2012, pp. 2-3). Obviously, prolepsis cannot be relegated to digitally scaffolded materials, but rather calls for teachers to recognise the proleptic inclusivepractice pedagogical potential in digital multimodal learning designs and how best to help learners (possibly also help other 
learners) recognise and avail themselves of the multimodal affordances in their planning, implementation and evaluation of their teaching.

In this way, van Lier's proposal for ecological language teaching can be augmented with the "offerings" of an inclusive multimodal learning design, helping teachers to do their probably most important part (van Lier, 2006, pp. 150-153), namely dealing with contingencies, i.e. teacher efforts addressing specific learners' ZPD. It seems reasonable to expect the UDL multi-level and multimodal digital scaffolds can help to optimise teacher efforts regarding contingencies, by already anticipating some learner contingencies in its inclusive design. Further, agency and action are similarly facilitated by the inclusive design, minimally at the level of individual textual apprehension. However, as a further result of inclusive design, peer scaffolding (cf. Donato, 1994) is possibly also assisted as peer-to-peer prolepsis and contingencies are facilitated, making it easier to establish common grounds in peer-to-peer dialogues and aid student collaboration.

Informed by scaffolding theory, multimodal theory and ecological perspectives on language teaching, we can thus build a coherent cross-pollinated UDL-CALL design. This design reinstates Dunkin and Biddle's (cf. Beatty, 2012, p. 146) original teacher presage variables: teachers' formative experiences shaping their teacher training in turn shaping their teaching skills to reflect more than software scaffolds and affordances, but also teachers affording themselves of the software and to become informed about affordances in dialectic dealings with both software and learners. Therefore, Dunkin's and Biddle's (Beatty, 2012, p. 14.6) teacher process variable "the teacher's behaviour" is reinstated, though slightly reformulated as "dynamic teacher planning, implementation and evaluation" (Beatty, 2012, p. 146). In the proposed model, dynamics result from both the interaction with learners ('behaviours) and the UDL-CALL software. The teacher's dynamic didactic efforts inter alia deal with prolepsis and contingencies. Dynamics also result from the teacher's interactive dealings with the GUI and software in planning, implementing and evaluating educational intentions, guided/inspired by students' and their interactions with the program and the GUI. This ecological understanding of the multimodally scaffolded UDL-CALL design also lets students interact dialectically with the GUI and program, the teacher and 
each other as illustrated by the green "dynamic-ecologicallyand-multimodally-scaffolded-collective-and-individual-learnerbehaviours" process variable of the design proposed.

Moreover, understanding ecological principles and their potential affordances for the multimodal CALL learning material design, it hardly makes sense to leave all innovation and software development to "software developers' collective experience", as suggested by to seek to avoid creating misaffordances and missing relevant user needs in the Beatty's model of a CALL design. Rather, the ecological UDL-CALL design recognises user (teacher and learner) affordances as resources in the design phase GUI and program. The present project is rather inspired by principles of participatory design (PD) (Sanders, 2003; Schuler \& Namioka, 1993) in which inter alia listening to user experiences, needs and advice and examining user interaction are of primary importance in the design phase. Although PD and other user-driven HCI (human-computer interaction) innovation formats have been with us at least since the nineties, in Beatty's CALL design model, innovation designs have surprisingly been banished - perhaps guided by a transmission-based and in part behaviourist understanding of CALL classrooms rather than an ecological one (2012, pp. 142-158). Therefore, I propose a multimodal UDL-CALL design integrating inclusive practice, multimodality theory from semiotics and HCI, scaffolding theory, ecological (second language) social-cultural-theoretical acquisition and teaching theory as well as PD to have a design that is theoretically as well as practically coherent.

However, in a coherent ecological understanding of UDLCALL learning designs, Dunkin and Biddle's (1973) as well as Beatty's (2012, p. 146) presage variables and context variables become recognisable as dynamic affordances. In other words, as ecological niches, classroom processes, developers, teachers and learners are connected in environments affording multimodal, inclusive, computer-assisted language learning design and development. Recognising these variables as dynamic and interrelated provides an understanding of the resources involved rather than seeing them as givens and unrelated immutable factors, as suggested in Beatty (2012, pp. 142-158).

The model of the multimodal UDL-CALL design makes room for long-term dynamic interrelatedness among long-term dynamic affordances. Long-term interrelations are indicated by thin curved arrows connecting them. The model of the 
design, therefore, depicts learners' formative experiences as also shaped by their long-term growth. Analogously, teachers' formative experience with inter alia UDL-CALL designs are seen to be shaped by their dealings with planning, implementation and evaluation in UDL-CALL practice. Crucially, both teachers and material developers are experientially informed by multimodal ecological scaffolding designs in their programming and teaching, respectively, which bears on the model of the cross-pollinated UDL-CALL design in Figure 2. The design also recognises schools and society as a dynamic affordance but its long-term interrelatedness with other elements has not been depicted, as this is no central concern of the design, being too long-term.

To understand inclusive multimodal CALL classroom interaction ecologically, dialectic connections using arrows from and to elements have been used. Classroom contexts are thus in a dialectic relationship with learner behaviours individual and collective, which are multimodally, ecologically scaffolded by the graphic user interface of the programs by dynamic planning, implementation and evaluation by the teacher as well as by dynamic learner properties, into which goes dynamic learner affordances which are in turn shaped by long-term learner growth.

On this basis, the following model of the multimodal UDLCALL hybrid is proposed. 
Figure 2. A proposal for a multimodal UDL-CALL design.

Dynamic affordances:

Developers

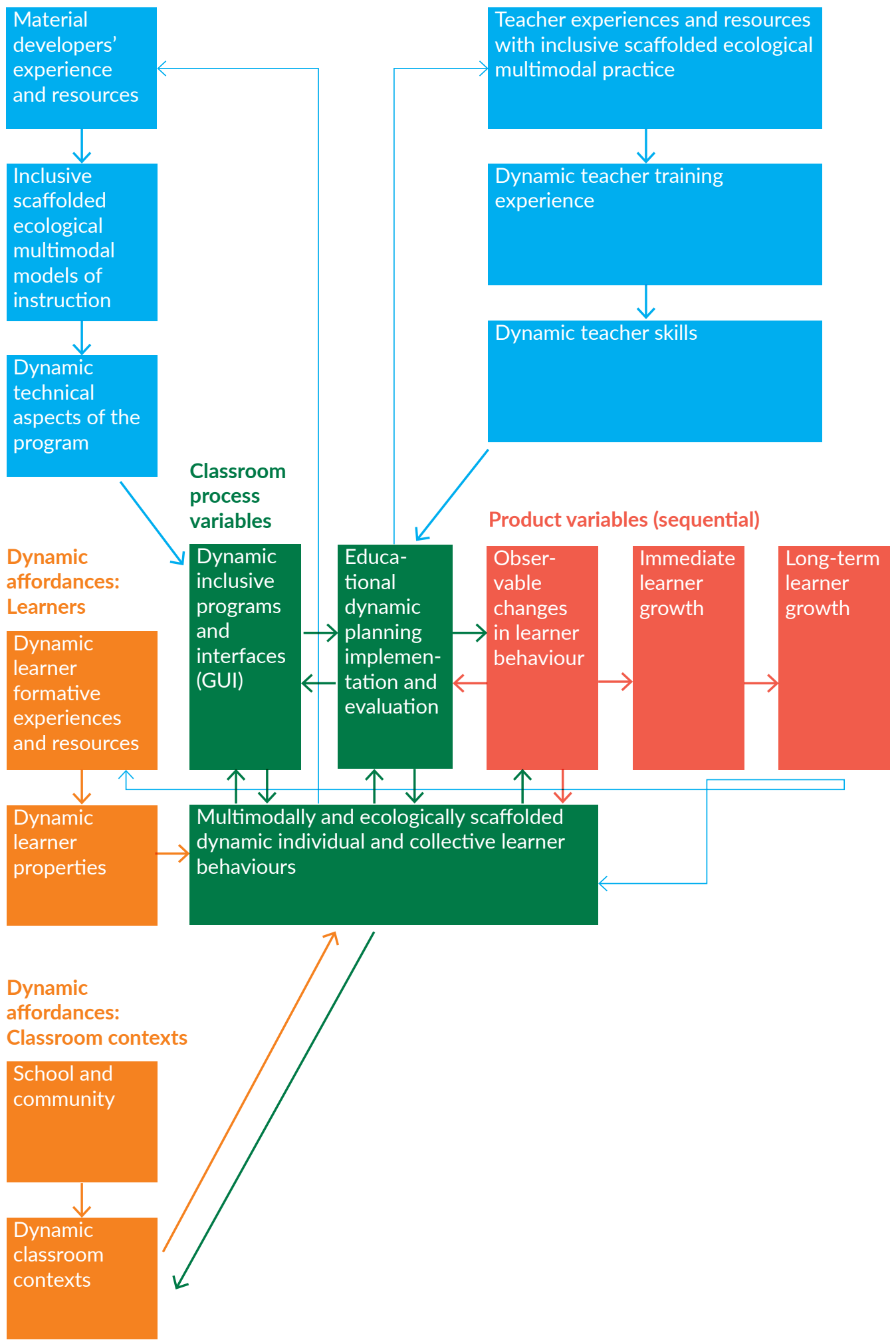

51 Learning Tech 05 | Multimodalitet i didaktikken og klasserummet 


\section{A Possible Testing of the Viability of the Multimodal UDL-CALL Hybrid}

In a nutshell, testing the viability of the UDL-CALL hybrid is a matter of examining the combination of inclusive practice and foreign language teaching aided by computer scaffolds. In my use of a UDL-platform for the design inspired by PD, feedback from learners and teachers alike is vital, as well as cooperation. The aim is to see if UDL-scaffolding will bolster ecologically sound practices supporting learner engagement and participation, involving action and autonomy.

As aforementioned, the project is crucially concerned with the UDL guideline "provide multiple means of representation" (1.1. - 1.3) in a CALL context. The research-based CAST.org Bookbuilder platform is used. Having obtained permission from the publisher, I have converted three course book texts from A Piece of Cake 7 to three Bookbuilder e-books. In terms of the UDL-CALL cross-pollinated design, I offer agency and action affordances by scaffolds not only in terms of scaffolding primary literacy agency as in Gissel's studies (Gissel, 2014, 2015) but to scaffold literacy and agency concerning foreign language comprehension.

The scaffolds may primarily reach out to struggling learners, but with universal designs, design elements originally intended for specific users may have other uses for other users (Rose, 2007) and a corollary hypothesis is that in providing sufficient help to struggling learners in a diversity of modalities, all learners are helped. One can argue that UDL scaffolding simply applies the well-known principle for task differentiation of "building the ladders long enough" featuring inter alia low entry-level tasks (Petty, 2013). In other words, if providing "lowentry-level" help, less struggling learners will easily find help in the help offered to struggling learners. Contrariwise, undue perceived "limiting of freedom" of more advanced students can be helped in instructional meta-scaffolding making it clear to students that scaffolds are meant to help and provide direction in the construal and that other (similar) understandings/wordings may be viable as well.

A mixed-methods design is used - featuring both qualitative and quantitative instruments and is collaboratively design-based so that learners and teachers alike are asked to contribute with suggestions for the digital scaffolds. Quantitative data are studied in screencasts recording learner interaction with the graphical 
user interface and will be used to supplement qualitative data from structured research "inter-views" (Brinkman \& Kvale, 2015) with learners. Both teachers and learners, so far including minimally three mainstream classrooms (between 20-27 students) from minimally three schools and their teachers will be interviewed and co-operated with. I shall take field notes for having a thick description of learning ecologies and interventions including teaching collaboratively planned, implemented and evaluated. From each classroom a learner sample of minimally five learners stratified according to the (1-5) intervals of the National Test in English-as-a-foreign-language (EFL) proficiency will be interviewed regarding their experiences using the scaffolds of the learning materials and also to provide suggestions for augmenting designs.

In the pilot phase, a teacher and I have thus tested and debugged e-books agreeing on teaching activities and learning goals for using the materials. In addition, I collaborate on the teaching itself, offering help and co-presenting today's assignments. The full testing design is in the making and so far deals with three digitally e-book learning materials to be used in 4-6 consecutive English classes in three year-seven classrooms in three Danish primary and lower-secondary schools. Nevertheless, findings obtained may necessitate further use of both qualitative and quantitative instruments and further e-books.

\section{Preliminary Results of a Pilot Study and its Limitations and Implications for Practice}

The pilot study is a part of an ongoing $\mathrm{PhD}$ project under the auspices of the VIS research programme ("Viden-I-Skolen", 2017). Two lessons in May and June were used for a trial run with plenary learner interaction and responses collected using two Bookbuilder beta-version e-books authored by me but subject to debugging (three corrupt glossary links were detected and reported by learners for both e-books tested). In the last session, screencasts of student-interaction were used.

Certain findings analysed in the pilot study deserve mention. In the second lesson, screencast data from nine out of 20 students were obtained, representing all the intervals in the Danish EFL proficiency test 1 (1), 2 (4), 3 (2), 4 (1) and 5 (1) in the June lesson showing that although there was a general downward 
trend (cf. Figure 4), the data display discontinuity. The small data set correlates aptitude scores (score in the Danish nationwide EFL proficiency test (vocabulary, language awareness and reading skills) with number of glossary look-ups split itself into three series:

$[(0,95),(6,84)],[(0,81),(0,79),(6,69),(16,5)]$ and $[(9,30),(85,71)]$

These findings appear to hint at complexity and individual category-independent variation rather than simple linear or curvilinear correlations. The average performance in the nationwide proficiency of the class and of the sample were slightly above 2017 national average by $(63-59=) 4$. (Undervisningsministeriet, 2017) and $(61,4,4-59=)$ 2,44 percentage points respectively, and hence representing a mainstream classroom. The range of glossary look-ups also

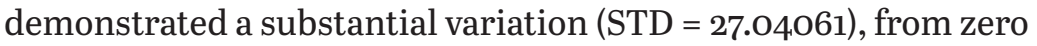
look-ups looking up no entries to 85 look-ups (including function words like "they" and primary verb forms like "were", "was". Since compendious glossing resources were exhausted, we may take this data to suggest a genuine need for inclusive glossing designs in mainstream classrooms, in turn suggesting the meaningfulness of a UDL-CALL design. The informant reported in both trial runs that $\mathrm{s} /$ he found the scaffolds useful apart from corrupt links, but owing to literacy issues, I might speculate that with due meta-scaffolding, s/he would have benefited even more, using sound scaffolds instead or supplementarily. From an ecological UDL-CALL design point of view, the bottom and arguable extreme set $[7,85]$ is therefore interesting and not to be considered an outlier.

In the plenary follow-ups, students, encouraged to be critical and report flaws, reported that the scaffolds were generally helpful with the exception of glosses with (partially) corrupt links just accessing the first entry of the glossary. Even without meta-scaffolding, three out of nine students used the response function (see Table 1 below) meant to have the student reflect on what they had read and engage them (cf. guidelines 2 and 3). However, looking at Table 1, both segregated data correlating time spent reading with aptitude level into responsefunction users and no-response users and non-segregated data leads to serially split scatter plotting, hinting at qualitative 
diversity of learner interaction - rather than a mere linear or curvilinear trend - both between groups and inside groups.

Unfortunately, possibly owing to want of instructional metascaffolding in the last session on how the scaffolds may be used for different purposes, no students had used sound scaffolds which is to be carefully considered by me and the teacher project partners when moving on to testing phases in SeptemberNovember 2018, making sure that instructional meta-scaffolding will feature more prominently.

\section{Conclusion}

This paper has demonstrated a theoretically and practically coherent cross-pollination of UDL and CALL informed by multimodal semiotics and theory, scaffolding and affordance theories and ecology-orientated socio-cultural theories of language learning and teaching, including usage-based theory. The theoretical discussions and gradual build-up of the UDLCALL design did not just unravel conditions for inclusive multimodal CALL classroom ecologies but also ecologies allowing for dynamic dialectics between learners, teachers and developers to make room for a participatory CALL software design. To explore UDL and CALL compatibility and translating UDL into multimodal scaffolding CALL formats, I used multimodal theory and multimodal semiotics to provide pedagogically sound formats. Traditional (non-digital) scaffolding theory was held up against UDL guidelines and used to analyse UDL digital scaffolds. The discussion examined Pea's understanding of non-faded digital scaffolds as distributed intelligence, suggesting that nonfading did not per se lead to spurious scaffolding: in this way, digital multimodal inclusive designs were not to consider as distributed intelligence potentially hampering learning.

Diversity in learners' uses of scaffolds in the pilot study manifested in this very preliminary study, indicating that no immediate one-serial correlation obtained between glossaryfunction usage and aptitude. However, a further finding was that additional theory was needed to supplement multimodality, scaffolding, affordance theory and ecological perspectives to work with UDL scaffolds in practice from e.g. language typology and contrastive awareness studies to implement UDL principles of how and what to scaffold in CALL designs.

Limitations of the present pilot study are obvious. In 
general, the data set was very small and serially split - per se inviting further studies. Such studies are needed to see if complexity and diversity are also reproduced in larger samples. Moreover, qualitative instruments like research "inter-views" (Brinkman, 2015) are needed for exploring students' experiences working in UDL-CALL learning environment to supplement screencast recordings. From perspectives discussed, therefore, further research, qualitative as well quantitative, into digital scaffolding is needed to see if informed inclusive CALL designs increase opportunities for action and engagement in the foreign language classroom, which will be taken up in testing phases starting as of January 2019.

Table 1. Aptitude Level and Score, Time, Response and Look-ups.

\begin{tabular}{|l|l|lll|}
\multicolumn{2}{l}{ Apitude } & Time & Responce & Look-ups \\
\hline 5 & 95 & 4.16 & YES & 1 \\
\hline 4 & 84 & 3.33 & YES & 6 \\
\hline 4 & 81 & 2.12 & NO & 0 \\
\hline 4 & 79 & 10.10 & YES & 0 \\
\hline 4 & 69 & 1.06 & NO & 6 \\
\hline 3 & 56 & 4.27 & NO & 6 \\
\hline 3 & 52 & 4.09 & NO & 16 \\
\hline 2 & 30 & 5.10 & NO & 9 \\
\hline 1 & 7 & 10.49 & NO & 85 \\
\hline
\end{tabular}




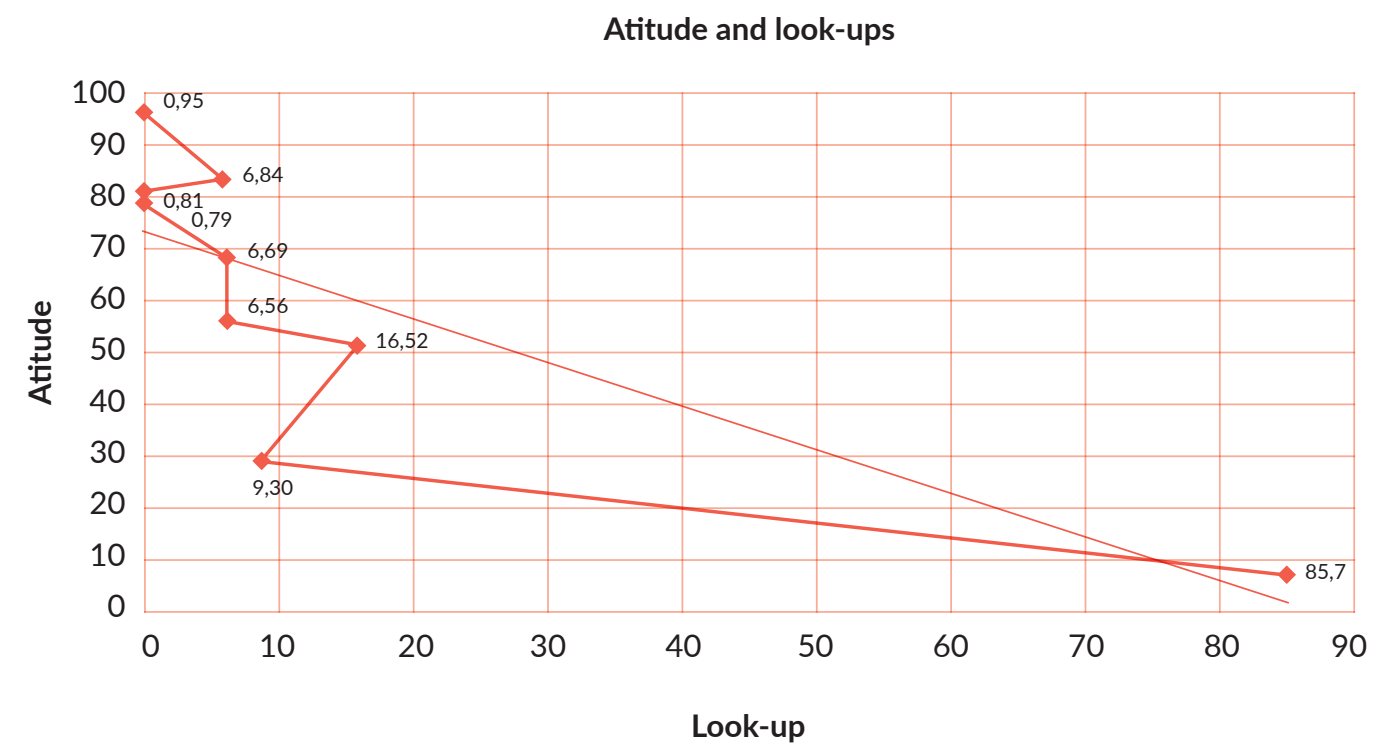

\section{Bibliography}

Bazalgette, C., \& Buckingham, D. (2013). Literacy, Media and Multimodality: A Critical Response. Literacy, 47(2), 95-102. DOI: 10.1111/j.17414369.2012.00666.x

Beatty, K. (2010). Teaching \& researching: Computer-assisted language learning. London \& New York: Routledge.

Bernsen, N. O. (2008). Multimodality Theory. In D. Tzovaras (Ed.), Multimodal User Interfaces (pp. 5-30). Berlin \& Heidelberg: Springer Verlag.

Bundsgaard, J., \& Hansen, T. I. (2011). Evaluation of learning materials: A holististic framework. Journal of Learning Design, 4(4), 31-44. DOI:10.5204/ jld.v4i4.87

Capp, M. J. (2017). The Effectiveness of Universal Design for Learning: A Metaanalysis of Literature between 2013 and 2016. International Journal of Inclusive Education, 21(8), 791-807. DOI: 10.1080/13603116.2017.1325074.

Chomsky, N. (1986). The Knowledge of Language as a Focus of Inquiry. In Knowledge of Language: Its Nature, Origin and Use (pp. 1-15). Westport: Praeger Publishers.

Chomsky, N. (1968). Cartesian Linguistics: A Chapter in the History of Rationalist Thought (Vol. 77). New York \& London: Harper and Row.

Clark, H. (1996). Using Language. New York: Cambridge University Press.

Clark, H., \& Brennan, S. (1991). Grounding in Communication. In L. B. Resnick, J. M. Levine, \& S. D. Teasley (Eds.), Perspectives on Socially-Shared Cognition. Washington, D.C.: APA Books.

Donato, R. (1994). Collective Scaffolding in Second Language Learning. In J. P. Lantolf (Ed.), Vygotskian Approaches to Second Language Research (p. 3356.). London: Ablex Publishing. 
Gibson, J. J. (1986). The Ecological Approach to Visual Perception. New York and Sussex: Psychology Press, Taylor and Francis Group.

Gissel, S. T. (2014). Talking Books in Reading Instruction and Student Behavior. Designs for Learning, 7(1), 76-98. DOI: 10.2478/df1-2014-0012.

Gissel, S. T. (2015). Scaffolding Students' Independent Decoding of Unfamiliar Text with a Prototype of an Ebook-feature. Journal of Information Technology Education: Research, 14, 439-470. Retrieved from http://www. jite.org/documents/Vol14/JITEv14ResearchP439-470Gissel2075.pdf

Hall, T. E., Meyer, A., \& Rose, D. H. (Eds). (2012). Universal Design for Learning in the classroom: Practical applications. (K. R. Harris \& S. Graham, Eds.), What works for special-needs learners. Wakefield, MA: Guilford.

Hansen, T. I., \& Skovmand, K. (2011). Foelles mål og midler - Loeremidler og loereplaner i teori og praksis. Århus: Klim.

Harmer, J. (2007). The Practice of English Language Teaching. Harlow, London: Pearsson.

Krashen, S. D., \& Terrel, T. (1988). The Natural approach: Language Acquisition in the Classroom. New York: Prentice Hall International Ltd.

Martin, J. R., \& Rose, D. (2005). Designing Literacy Pedagogy: Scaffolding democracy in the classroom. In J. Webster, C. Mathiessen, \& R. Hasan (Eds.), Continuing Discourse on Language (pp. 1-26). London: Continuum

Mohsen, M. A., \& Balakumar, M. (2011). A Review of Multimedia Glosses and Their Effects on L2 Vocabulary Acquisition in CALL Literature. New York: Cambridge University Press. DOI: 10.1017/So95834401100005X

Pea, R. D. (2004). The Social and Technological Dimensions of Scaffolding and Related Theoretical Concepts for Learning, Education, and Human Activity. The Journal of the Learning Sciences, 13(3), 423-451. DOI: 10.1207/ S15327809jls1303_6

Pinker, S. (1995). The Language Instinct. New York: HarperPerennial.

Plonsky, L., \& Ziegler, N. (2016). The CALL-SLA Interface: Insights from a Second-Order Synthesis. Language Learning \& Technology, 2o(2), 17-37. DOI: $10125 / 44459$.

Prensky, M. (2001). Digital Natives, Digital Immigrants. On the Horizon (MCB University Press), 9(5), 1-6. DOI: 10.1108/1074,8120110424,816

Rose, D. H. (2007). Universal Design for Learning and the Future of Education. The 2007 Federation for Children with Special Needs' Visions of Community Conference.

Sanders, E. B.-N. (2003). From user-centered to participatory design approaches. In Design and the social sciences (pp. 18-25). Florida: CRC Press.

Schmidt, R. (2010). Attention, awareness, and Individual Differences in Language Learning. In W. M. Chan, S. Chi, K. N. Cin, J. Istanto, M. Nagami, J. W. Sew and I. Walke, (Eds.), CLaSIC 2010. Singapore: National University of Singapore, Centre for Language Studies.

Schuler, D., \& Namioka, A. (1993). Participatory design: Principles and practices. Florida: CRC Press.

Stæhr, L. S. (2015). Ordforrådstilegnelse - fundamentet for kommunikativ kompetence. In A. S. Gregersen (Ed.), Sprogfag iforandring: pcedagogik og praksis (pp. 169-200). København: Samfundslitteratur.

Stockwell, G. (2007). A review of technology choice for teaching language skills and areas in the CALL literature. ReCALL: Journal of Eurocall, 19(2), 105-120. DOI: 10.1017/So958344007000225 
Undervisningsministeriet. (2017). National Test Engelsk 7. Klasse.

Copenhagen. Retrieved from internal-pdf://o.193.173.68/Nationaltest i engelsk hele landet.docx

van Lier, L. (2000). Sociocultural Theory and Second Language Learning. Oxford: Oxford University Press.

van Lier, L. (2004). The Ecology and Semiotics of Language Learning: A Sociocultural Perspective. New York, Boston, Dordrecht, London \& Moscow: Kluwer. Retrieved from internal-pdf://252.140.111.186/van Lier L The Ecology and Semiotics of Langua.pdf

Viden-I-Skolen. (2017). Retrieved November 19, 2018, from https://www. ucn.dk/forskning/forskningsprogrammer/professionsudvikling-oguddannelsesforskning/viden-i-skolen-vis

Villada, E. G. (2009). CALL Evaluation for Early Foreign Language Learning: A Review of the Literature and a Framework for Evaluation. San Marcos: Computer Assisted Language Instruction Consortium. DOI: 10.1558/ cj.v26i2.363-389

Vygotsky, L. S. (1978). Mind in Society - The Development of Higher Psychological Processes. Cambridge, Massachusetts \& London: Harvard University Press.

Wakefield, M. A. (2011). Universal Design for Learning Guidelines Version 2.o. CAST. Retrieved from https://wvde.state.wv.us/osp/UDL/4. Guidelines 2.0.pdf

Wood, D., Bruner, J. S., \& Ross, G. (1976). The Role of Tutoring in Problem Solving. Journal of Child Psychology and Psychiatry, 17 (2), 89-100. DOI: 10.1111/j.1469-7610.1976.tboo381.x

Zafar, M. (2010). Monitoring the "Monitor": A Critique of Krashen's Five Hypotheses. The Dhaka University Journal of Linguistics, 2(4), 139-146. DOI: 10.3329/dujl.v2i4.6903

Zhang, L. (2017). Analysis on the Role and Functions of Teachers, Teaching Materials and Learners in the Multimedia-aided English Classroom-Based on the Study of Linfen No. 1 Senior School. Theory and Practice in Language Studies, $7(11)$, 1132-1138. DOI: 10.17507/tpls.0711.24 


\section{Learning Tech - Tidsskrift for læremidler, didaktik og teknologi Udgives af Læremiddel.dk}

Learning Tech er et forskningstidsskrift, hvor alle artikler er forskerbedømt i form af dobbeltblindt peer review. Tidsskriftet bringer artikler, der rammer genstandsfeltet mellem læremidler, didaktik og teknologi, og hensigten er at spille en betydelig rolle som platform for den voksende skandinaviske læremiddelforskning.

\section{Redaktion}

Stig Toke Gissel, UCL Erhvervsakademi og Professionshøjskole (ansvarshavende redaktør)

Anne-Mette Nortvig, Professionshøjskolen Absalon

Bettina Buch, Professionshøjskolen Absalon

Hildegunn Juulsgaard Johannesen, University College Syd

Marie Falkesgaard Slot, UCL Erhvervsakademi og Professionshøjskole René Boyer Christiansen, Professionshøjskolen Absalon

Stefan Ting Graf, UCL Erhvervsakademi og Professionshøjskole Stine Reinholdt Hansen, UCL Erhvervsakademi og Professionshøjskole Thomas R.S. Albrechtsen, University College Syd

\section{Redaktionssekretær}

Trine Ellegaard, UCL Erhvervsakademi og Professionshøjskole

\section{Temaredaktion}

Stig Toke Gissel, UCL Erhvervsakademi og Professionshojskole Bettina Buch, Professionshojskolen Absalon

Stine Reinholdt Hansen, UCL Erhvervsakademi og Professionshojskole

\section{Design og grafisk tilrettelæggelse}

Trefold - grafisk design og kommunikation

\section{Tryk}

Narayana Press, Gylling

ISSN 2445-7981 (Tryk)

ISSN 2445-6810 (Online)

\section{Rettigheder}

(c) 2018 Læremiddel.dk og forfatterne

\section{Kontakt}

Læremiddel.dk, Niels Bohrs Allé 1, 5230 Odense M www.laeremiddel.dk 